ARTICLE

https://doi.org/10.1057/s41599-019-0379-6

\title{
Guns in Bangla cinema across borders: perspectives on cultural evolution
}

Sabiha Huq (iD ${ }^{1 \star} \&$ Srideep Mukherjee ${ }^{2}$

\begin{abstract}
In tracing a specific trajectory of cultural evolution, this paper builds upon Jean Baudrillard's concept of 'simulacrum', arguing that the use of guns in Bangla cinema from Bangladesh and West Bengal (India) is connected with 'hyper-reality' and 'simulation'. The authors hold that both are symptomatic of the unreal nature of contemporary Bengali culture in an age of mass consumption. A perusal of Bangla cinema following the Partition of India (consequently, of Bengal too) in 1947, and the Liberation war of Bangladesh in 1971 shows a tradition of ample use of guns and ammunition. The authors perceive three distinct phases of such representation-films from West Bengal highlighting Partition violence around 1947; exponents from Bangladesh upholding the independence of former East Pakistan in 1971 and the brutality of the West Pakistan armed forces; and hyper action in contemporary commercial cinema. The last category is perceived by and large as hyperrealist, for it substitutes 'the signs of the real for the real itself'. Basing upon Baudrillard's contention that we have lost our capacity to grasp reality as it is, and need to depend on set-up realities in a virtual world, this paper claims that the initial patriotic zeal (its remnants notwithstanding) of Bangla cinema has taken a retrogressive turn, so as to seek recourse in representations of violence as channels of personalised/disorganised pseudo-real entertainment like video games. This undoubtedly signifies the confusion of cultural values. The paper hypothesises that the first two categories qualify as cultural texts attempting to approximate historical realities, wherein guns function as vital symbols of power and unity, resistance and liberation. The third category, conversely, is another façade of culture-one that symbolises the present time as an 'age of simulations' that hardly has any organic connection with ground realties that the films claim to contextualise. The authors from either side of the India-Bangladesh border intend to focus on the use of guns in Bangla cinema of these three evolving phases, applying film analysis to select productions from Bangladesh and West Bengal in India. The paper is conceptualised as a substantial contribution to film and cultural studies, as this area has hitherto remained uncharted in academic discussion.
\end{abstract}

\footnotetext{
${ }^{1}$ Khulna University, Khulna, Bangladesh. ${ }^{2}$ Netaji Subhas Open University, Kolkata, India. *email: sabiha.huq@eng.ku.ac.bd
} 


\section{Introduction and scope}

he years from 1947 when colonial India was first partitioned on the basis of the 'Two-Nation' theory to 1971 when this very theory proved fallacious as Bangladesh (formerly East Pakistan) proclaimed her independence from Pakistan, have been a tumultuous phase of history in the Indian subcontinent. While each of the three nations has in turn developed its indigenous version of macro-history that further problematises the South Asian scenario, there is also the simultaneous existence of cross-cutting discourses of ideological dissent in post-colonial critiques underlying the founding principles of these nations. For instance, in the cases of India and Bangladesh, which form the geo-political core of this paper, the assassinations of Mahatma Gandhi (1948) and Sheikh Mujibur Rahman (1975), both key architects of the destinies of their people who fell to gunshots fired point blank at them, are pointers to the sociological understanding that 'nations ... are constituted in selfcontradictory struggles ... that are prolonged and in some senses endless' (Pandey, 2012, p. 290). In the collective unconscious of both nations therefore, the signification of guns as firearms that have created a counter-discourse to the national imaginary, has had currency right from the time of their birth. In this paper, the authors choose to historicise the multiple matrices of nations and their attendant cultures by concentrating on the deeper and symbolic significations of guns-both visual and theoretical. ${ }^{1}$

The gunning down of the Mahatma in full public view and of Bangabandhu Sheikh Mujibur Rahman in stealth were tantamount to acts of parricide, the immediacy of which had plunged both new born nations in shock and anomie. In its time, such determined actions as exhibited by the assassins of Gandhi and Rahman would strike as a violent discourse that questioned all fixities of emergent nationhood. However, looking back over a longue duree and specifically from an academic viewpoint, the potency of guns has long surpassed their denotative value as instruments of carnage, and has connotatively foregrounded ideological opposition in exemplary ways. As we attempt to read through the passage of the Bengali race from postcoloniality to neocolonialism in a global order through cinematic representations, a brief perusal of history would be in place to comprehend why the sub-cultures of violence as embodied through the use of guns have become necessary to reconnoitre with new definitions of reality.

The post-colonial history of the Bengal province (a term from colonial history) of hitherto undivided India is one of repeated partitions unseen anywhere else in the subcontinent. Even if the first partition of 1905 (later repealed) is left out of the present purview, the cataclysmic Indian partition of 1947 split Bengal into East and West, with the former being earmarked as a predominantly Muslim habitation and hence accorded to Pakistan. It was, however, beyond (West) Pakistan's socio-political understanding to contain the undaunted spirit of Bengali nationalism with a coercive-repressive state apparatus, hence in 1971 (as mentioned earlier) Bangladesh liberated herself from the Islamic Republic of Pakistan. In statist terms however, this too was a split - one that might not have recalled the ghosts of sub-human population exchange of 1947, but definitely besmirched with the despicable brutality of battle-violence, arson, rape and mutilation, and uncertain fortunes for millions of refugees, before the Mukti Bahini could finally achieve victory with the active support of Indian forces and get Pakistan to sign the Instrument of Surrender on 16 December 1971 in Dhaka. It is obvious that an otherwise peace-loving and largely non-combatant Bengali people have thus repeatedly been prompted to embrace arms, mostly for purposes of self-preservation. It is in this continuing light of nation formation that the paper proposes to study the use of firearms, specifically of guns, in Bangla cinema, which is surveyed as a prolonged representation of socio-cultural life of the community. The scope of the nomenclature of Bengali, it must be clarified, goes beyond nationalities and is a linguistic identity that includes people whose origins lie either in the Indian province of West Bengal, or present day Bangladesh.

As indicated in the Abstract, this paper uses a method of purposive sampling in selecting representative Bengali film texts from Bangladesh and West Bengal (India), holding as an apriori the historically documented seamless strength of the Bangla language, its composite cultural roots, and nationalism that binds a syncretic Bengali speaking people whom partition has by force torn asunder. With the use of guns as motif, and drawing upon the phases of history previously enumerated, the authors periodise such films into three distinct categories-those based on the partition of India and thereby of Bengal in 1947; films depicting the Liberation of East Pakistan and the independence of Bangladesh in 1971; and those that are temporally-spatially located in more recent times wherein the range of subjects include border conflicts, internal strife, or are inclined to produce some simulated realities. With a view to keeping a common ground between films from Bangladesh and West Bengal, cinematic representations of intervening topical issues such as the historic Language Movement in Bangladesh (1952), the Mass Movement of 1969, or the Indo-Pakistan war of 1965 have been kept out of the sampling frame.

The present paper is part of a larger project that intends to investigate the representation of firearms in different media with a geo-spatial focus that spans from the national to the global. To this end, it theorises the evolution of its chosen texts on Jean Baudrillard's concept of 'simulacrum'. Through their perusal of the three representative phases of Bangla cinema from the perspective of the use of guns as producing evolutionary domains of 'reality', the authors argue that there is an undeniable movement from the real/historical to the hyperrealist. In Baudrillard's terms, the latter, instead of becoming symbolic of the real, begins to create its own 'reality'. Our contention in this paper is that over a period of time, the representation of guns and firearms in Bangla cinema from Bangladesh and West Bengal is visibly creating dialectics of the real and the imaginary. While films of the first phase are replete with the urgencies of the impact of partition upon hapless civilians catapulted as victims of high-politics; those of the second (which comes a quarter century later) are pervasive with the agency and zeal that a long-suppressed people exhibit as they carve out their independent homeland. In comparison, films of the third category, which are temporally located more than half a century/another quarter century apart from those of the first and second categories respectively; increasingly show a retrogressive turn towards mindless violence that corresponds with forms of entertainment that have a perverse impact on consumers in an age of mass consumption. For reference's sake the recent attack on innocent people in New Zealand can be referred to by a racist PUBG (Player Unknown's Battlegrounds, a popular mobile game) player. With the historical mainframe as specified, and incorporating relevant understandings of state policy (or the absence of it in market economies as far as the popular culture industry is concerned), we hypothesise that the first two categories qualify as cultural texts attempting to approximate historical realities, wherein guns function as vital symbols of power and unity, resistance and liberation. The third category, conversely, is another façade of culture-one that symbolises the present time as an age of video games or 'age of simulations' (Baudrillard, 1983, p. 4) that hardly has any organic connection with ground realties that the films claim to contextualise. 


\section{The Bangla film industry: a brief history of the early years}

The history of the Bangla film industry in undivided Bengal dates back to the closing years of the nineteenth century when Hiralal Sen, a native of Bagjuri (near Dhaka) made a film A Dancing Scene from an opera, using a borrowed camera. Subsequently, he equipped himself with a film projector and formed the Royal Bioscope Company (1898), which continued to make silent films depicting scenes from theatrical productions enacted at Kolkata (formerly, Calcutta) playhouses. These bioscope productions may be seen as the earliest beginnings of cinema in undivided Bengal. In a creative career that spanned till 1913 when the company made its last film, Sen is said to have made about forty short films. For the record, he is credited with having made the first political film, as also used the media for making advertisement films in Bangla.

While production houses started coming up gradually in Kolkata, cinema halls in and around Dhaka continued to screen bioscope shows produced elsewhere in the country. Eventually 'Picture House' came up in Dhaka, which began to screen sequential bioscope shows, and emerged as the first theatre to have been built in present day Bangladesh. Still in the silent era, in Kolkata, Madan Theatre made the first Bengali language feature film Billwamangal (also known as Bhagat Soordas) in 1919 , while the first talkies movies came in the decade of the 1930s. With the coming of the talkies, new studios began to come up in Kolkata, and of these, New Theatres was the most prominent. The first short silent film to have been shot in Dhaka (1928), and produced by the nawab family was titled Sukumari (The Noble Virgin), and later a full-length silent film titled The Last Kiss released in 1931 from the same production. Eventually in Dhaka, the East Pakistan Film Development Corporation was established in 1957, and this gave rise to three studios. Following the Liberation of Bangladesh in 1971, the East Pakistan Film Development Corporation evolved as the Bangladesh Film Development Corporation that has hence played a major role in the development of the film industry.

Taking this history a little back in time, after 1947 the Bangla film industry in the main, split between Kolkata and Dhaka, showing remarkable differences of trajectory with regard to the partition-independence of India. The event of 1947 partition did not get as much attention from film directors in East (Pakistan) Bengal as it did from Indian film directors, who responded late no doubt, but have produced a significant body of work. As Raminder Kaur (2017) observes in 'Skipping Memories on Partition and the Intersensory Field in Subcontinental Britain', as a trend, South Asian visual culture has always responded late by way of direct representation of the manifold traumas of partition. In fact it was only in the decade of the 1970s and 1980s that films like M. S. Sathyu's Garam Hava (Scorching Winds, 1974) and Govind Nihalni's Tamas (Darkness, 1988) stormed the Indian scene. This culturalist understanding of Indian partition on the Western frontier does not, however, square with the scenario of the Eastern theatre, ${ }^{2}$ and the reasons behind this are not difficult to trace. For East Pakistan, the period beginning in 1947 was largely another phase of colonisation, and more gruesome at that, since it was a rabid form of internal colonisation that left the Bengali population aliens in their 'own' land. It is felt by and large that the crises, which ensued in the state politics of Pakistan, causing its Bengali speaking Eastern wing to receive incessant battering from the Urdu dominated West led to an amnesia about partition, while the celebration of independence from colonial rule never really got under way. It is, therefore, understandable why topical events like the movements for right of Bangla as mother tongue, the language martyrs of 1952, the mass movement of 1969, and finally the Liberation War of 1971 have been more in focus in contemporary films from East Pakistan. Among significant films of this period, one might mention Nazir Ahmed's Salamat (1953); and Abdul Jabbar Khan's Mukh o Mukhosh (The Face and the Mask, 1956), the latter being the first full-length feature film with sound made in East Pakistan and its processing work was done at Lahore. While the former visualises the changes of the old Dhaka city and the emergence of a new city through a mason's eyes and evidently has no scope for use of firearms, the latter presents the story of a young boy who is found in a state of injury by a group of bandits who treat the boy with utmost cruelty. A dishonest police officer is in cahoots with the bandits. The boy's miseries end when a group of people fight against the bandits and rescue him. With armed skirmishes between the bandits and the police forming the major action of the film, one does see the use of firearms in Mukh o Mukhosh. As a trend, however, the availability of weapons was scarce for the police, and more so for civilians; and as such guns or firearms are hardly noticeable in films of this period. Mostly one or two rifles are used in the film as the only firearms, and the victory of unarmed civilians over armed bandits upheld a semblance of poetic justice, with which contemporary audiences identified and exulted. This is to suggest that the ethical sway of morality and the force of truth pervaded the collective unconscious of the time. The authorial perception of films of this phase from East (Pakistan) Bengal is that they conform to the realistic representation of a Bengali society trapped in a limbo between national identity, cultural-religious dissent, angst of the loss of roots and resettlement, and above all, aspirations and struggle for the assertion of selfhood that the West Pakistani dictatorship had perforce subverted.

Compared to this trend, even in the golden period of Bangla cinema from West Bengal where we find globally acclaimed directors like Satyajit Ray and Mrinal Sen addressing diverse vignettes of post-colonial matrices in their masterpieces to critical global acclaim, the highly relevant provincial issue of Partition remained equally in focus. Although it is not within the scope of this paper per se, yet a few words may be pertinent in tracing the historiography of cinema from West Bengal. One must mention in this context Nimai Ghosh's Chinnamul (The Uprooted, 1950), a film about the partition of Bengal that depicted the poignance of the refugee crisis, which it actually took to a global platform. The works of Ritwik Ghatak (who was originally from East Pakistan and was a refugee in Kolkata himself), especially his trilogy made in the 1960s, are similarly a moving commentary on the aftermath of Bengal partition. Ideologically, Ghatak could never come to terms with the partition of Bengal, and his trilogy Meghe Dhaka Tara (The Cloud Capped Star, 1960), Komal Gandhar (E Flat, 1961), and Subarnarekha (The Golden Thread, 1962) vividly explores the manifold violence to Bengali culture wrought by the Partition. The output of the West Bengal film industry has thus been both phenomenal and diverse. As document of human life and Bengali culture, cinema has touched upon issues like contemporary social unrest and radical politics in Mrinal Sen's films like Padatik (The Guerrila Fighter, 1973) and Chorus (1974); evolutionary facets of human relations in emergent post-colonial times in all works of Satyajit Ray Pather Panchali (Song of the Road, 1955) onwards; and in Ritwik Ghatak's powerful forays into the contested terrains of sociological issues following partition.

As will be evident from the foregoing discussion, the use of guns in Bangla cinema has in the main picked up in relatively recent times. As such, apart from documentaries, which are not the subjects of discussion in this paper, films of the first and second phases that we have outlined above, are mostly the ones made from the vantage point of looking back at historical epochs. There could be several factors behind this temporal distancing 
between the violent phases of history and the actual representation in films of the culture of guns and other ammunitions that came to play a major part in circumscribing the life and times of the Bengali race. The sociological reasons may be traced in the necessity of providing for some intervening time from the longranging nature of cataclysmic events to the representation of such violence. From the point of film historiography, one of the most important factors was definitely the increasing global influence of Hollywood action films. Besides, in a situation where it was difficult to borrow/acquire guns from government armoury or licensed sources for such film shoots, it was only with the mass production of artificial guns that such films could have been planned. In this regard, the authors received interesting insights from Tanvir Mokammel, a Bangladeshi director of repute who has recurrently dealt with the theme of Bengal partition in many of his works. Given that Mokammel's films show minimal use of firearms even when he is dealing with one of the most volatile phases of Bangladeshi history, he was asked about research on contemporary governmental policy documents regarding the use of ammunitions by Muktijoddhas (civilian armies operating under guerrilla tactics) as shown in films of the Liberation War. Mokammel's reply on this issue validates the assumptions laid down in the preceding lines:

Historically the Bengalis were a non-combatant nation. So firearms were dear here. The freedom fighters, mostly ragtag guerilla units, used any kind of gun they could marshal or lay their hands on, especially during the first phase of the war. Later when the liberation war became better organised and gathered momentum and trained guerilla units were being sent inside the country, an average guerilla unit would generally have some rifles, along with a few stenguns, one or two mortars, and some hand grenades. My films, and films on the Liberation War generally, show those weapons. But to collect those weapons for filming was never easy. For example, during the shooting of my film Nadir Nam Madhumati I (The River named Madhumati), as the then government was an anti-liberation one, we could not collect any firearm from any government sources to shoot the film realistically. We approached the Bangladesh Army, the Bangladesh Rifles (BDR), even the police, but failed everywhere. That is why, the battle-scenes or the action-scenes of Nadir Nam Madhumati have remained so weak. (Huq, 2019).

\section{Films on the Indian/Bengal partition of 1947:}

Chitra Nadir Paare (1998) from Bangladesh. Tanvir Mokammel's Chitra Nadir Paare (Quiet Flows the River Chitra), based on the Partition, depicts the archetypal dilemma of a Hindu family in East (Pakistan) Bengal over migrating to India, which was posited in the pogrom of displacement and population exchange as a safer abode for Hindus. The protagonist is Shashikanta Sengupta, an eccentric lawyer living in his house in Narail, a small provincial town on the banks of the Chitra. Like most people in his predicament, he too refuses to leave his motherland. Widower Shashikanta's family comprises of his two children, Minoti and Bidyut, and an old aunt Anuprava Devi who lives with them. The ambivalence that characterises relations between Hindus and Muslims in this period of Bengali history is present in this film as well. While Shashikanta's Muslim neighbours are eyeing his property, his daughter Minoti has long been in love with Badal, the son of their Muslim neighbour. Badal goes to Dhaka University and as the film is set in post Partition East Pakistan, the movements and riots of the 1960s are shown in the film. Badal gets involved in anti-military student movements and while participating in a demonstration for democracy, gets killed by firing. The use of guns is kept covert here, and Badal's death is only reported by his sister to his beloved Minoti, who comes home calling upon him.

Shashikanta's brother Nidhukanta is a doctor who lives on the other side of the Chitra. During the 1964 communal riots between Hindus and Muslims, his daughter Basanti, a widow, is raped. Basanti commits suicide by drowning herself in the Chitra, and Nidhukanta's family decide upon migrating to India. Shashikanta's failing health cannot bear these tragic incidents and he suffers a cardiac attack and passes away. Finally, Minoti and Anuprava leave for Kolkata. While the film ends here, the uncertainty of the plight that awaits these two destitute women in their condition as refugees hardly remains a matter of conjecture.

In this representative story of communal discord, of neighbours turning predators in an orgy of ideological hatred, and of armed civilian strife culminating in loss of innocent lives and uncertainty for uprooted masses, one finds Mokammel's hardhitting critique of the political expediency that underlay the partition of the subcontinent on religious lines. To Bengalis on both sides of the newly laid out international border, and to the people of East (Pakistan) Bengal in particular, independence that was declared on 14/15 August 1947 was hardly a panacea. The division of territories by the Radcliffe Line between India and Pakistan that was finally declared on 17 August 1947, and which came to have much more realistic impact in human terms compared to the nationalist rhetoric of independence on both sides of the border, comes alive in films like Chitra Nadir Paare. Visibly, the use of guns in this film is minimal, only the police as the face of Repressive State Apparatus are seen as having guns; and as the victim(s) of such a trigger-happy force, the hapless condition of innumerable youth like Badal itself becomes a moving comment on guns as being emblematic of the dividing lines that are drawn out between the ruler and the ruled, even in an 'independent' nation. In the interview with the director mentioned earlier, he informed the authors that Shashikanta's character was based on a real person, a lawyer who used to be their neighbour when his family lived in Narail during the period his father was posted there as a government official. It is, therefore, possible to blend fact and representation to rationalise upon the use of, or lack thereof, of guns in films of this period from Bangladesh. Indeed, film directors of Mokammel's stature are all fond of traversing the historical trajectory of Bangladesh and remain as faithful to it as possible.

Rajkahini (2015) from West Bengal, India. In quite another view of the human perception and representation of partition, Srijit Mukherjee's, Rajkahini [Tale of the (British) Raj] is a postcolonial take on the cataclysmic event of Indian partition from a position of Subaltern Studies, where the welding of guns by the gendered subaltern subject/victims marks an important departure from macro-histories of Partition and their representation that have currency in popular media. While most partition narratives locate women's histories against agonising circumstances of rape, mutilation, and murder of hapless victims as paradigms of defiling the body-politic of new nations, ${ }^{3}$ Mukherjee privileges a different history-that of a group of sex workers whose already liminal social identity is further jeopardised in a turbulent political milieu, their training in guns and resorting to gunfire for self-preservation, and their final determined resolve of selfannihilation rather than yielding to divisive machinations of state forces.

Set against the backdrop of the arbitrary division of territories between India and Pakistan as demarcated by the Boundary Commission headed by Sir Cyril Radcliffe constituted in July 
1947, Rajkahini is located along the border towns of Haldibari in North Bengal (India) and Debiganj (under Rangpur district in East Pakistan). As the Radcliffe Line stands on the map, government officials find that the fence of barbed wires must pass through a topography on which now stands a brothel, strategically located as it is on the outskirts of both these towns. As the 'other' of civil society, such location by itself is a poignant commentary on the hypocrisy embedded in the collective unconscious; hence concerns for the inmates of the brothel in such infested times finds no stake-holders, either among clients or patrons of some important standing. The mistress of the house, Begum Jaan, herself a woman of ambivalent religious identity, her women, her Pathan henchman and Bengali pimp-all share an inextricable bond that gives them a degree of autonomy against the wider society, but is still poor safeguard against the liminality of their social positions. In the context of emergent religious tensions being manufactured between Hindus and Muslims so as to force people to flee home and hearth and thereby expedite exchange of population as designed by colonial forces in collusion with mainstream Indian politicians, Begum Jaan's 'kotha' shows an obstinate kind of autonomy and resilience too. It is a 'nation' unto itself, with limited agency of the female body in exchange of money as the only terms of transaction; and the inmates are essentially unfazed by considerations of religious or caste identities that foments all the tension outside its walls. It thus follows that these women neither have any understanding whatsoever of emergent geo-political boundaries or questions of national identity; nor can they be bullied into being defiled physically, for unlike homebound women who were raped and killed in millions, the sex worker's body is already sold. Hence they stand their ground against persuasive and coercive moves for eviction by designated government officials, and the latter are perturbed over accomplishing their mission of eviction.

Given the rigid insistence of Begum Jaan not to move out, and of her women to stand by each other against adversity, the authorities nominated by the Indian National Congress and the Muslim League take recourse to extra-legal means. They hire professional killers with specific instructions to wipe out the inmates, while statist forces shall look the other way. The Nawab of Rangpur, hitherto a royal patron of Begum Jaan, is himself in the process of giving up his rights on the princely state and hence has no more political expediency left to save the brothel from destruction. However, he of course makes available abundant stock of country made guns and ammunitions for their selfpreservation, should the turn of events so allow.

For all the theatricality of its visual effect, Mukherjee shows the transformation of the female body from its hitherto disinterested acts of passive acquiescence in vacuous promiscuity to training in pellets, in preparation of the final battle. Eventually, the resolve of the women to stand their ground and assert their autonomy amidst the carnival of inhumanity and arson raging the land, their readiness even in an unevenly pitched gun-battle against a band of organised killers makes for a supreme moment of subaltern resistance. The battle rages for a while and it claims a toll of some of the inmates, and this is followed by the 'haveli' being set on fire by the armed goons, even as they smell an opportunity to ravish the half-burnt and injured women. Having run out of ammunition, the women however use their guns as clubs to fight back for as long as they can, refusing to surrender the agency of their female bodies to marauders, and rather fall to their deaths-burnt, bruised, but not defiled. Mukherjee makes exceptional artistic use of horror as Begum Jaan fires one last shot to rid her Pathan henchman (he is seen running out of the house with his body all aflame) of the indescribable pain of life-in-death. In a supreme gesture of injured pride culminating in final defiance against the bestiality of partition engendered violence,
Begum Jaan and four of her surviving compatriots re-enter the crumbling edifice of what was once their world, shut the doors to the cannibalistic world without, and choose self-immolation in the raging fire. The semiotics of the film gains by intertextuality as Thamma, the old mother figure in the 'haveli' continues to read out from Abanindranath Tagore's eponymous novel, the account of Queen Padmini of Chittor (Rajasthan) and her twelve thousand women followers who committed Jauhar to protect their honour from the Mughal army. ${ }^{4}$ The equivalence of Begum Jaan's act with Padmini's, the latter being a glorious episode of female agency/resistance in medieval Indian history, takes the use of guns in Mukherjee's Rajkahini ${ }^{5}$ to a new level of signification, even as it concludes the rites of assertion by the gendered subaltern in the film.

\section{East Pakistan from 1947 to 1971: history, policies and implications}

The intervening years between 1947 and 1971, though not specifically a part of this paper, demand at least a skeletal understanding in order to comprehend the hostilities that marred the relations between the Western and Eastern parts of Pakistan, the stakes that India had in the 'internal' matters of her eastern neighbour, and above all, the mass embracing of arms (of whatever kind the common Bangladeshi could lay their hands on) by the historically peace-loving Bengali people. Notwithstanding the emotional fervour with which people in Dhaka welcomed the creation of Pakistan in August 1947, the issue of official language became one of the earliest points of discord between the two flanks of the 'moth eaten' (as Mohammad Ali Jinnah himself had infamously called Pakistan) country. Against the West Pakistani assertion that Urdu was to be the state language, and the slur of imperfect Muslims used for the Bengalis of East Pakistan, the province erupted for the first time in 1952 when student demonstrations in Dhaka were fired upon by the police. After a long drawn conflict, in 1954 the National Assembly was compelled to designate both Urdu and Bangla to be the official languages of Pakistan.

Over the years however, the ethnic and provincial nature of political loyalties, the absence of a proper Constitution and then the lack of political will to ever implement it in spirit, and realistic apprehensions surrounding the domination of the West Pakistani province of Punjab-there were reasons galore for demands for provincial autonomy in the East. The new Constituent Assembly of Pakistan in 1955 that had a sizeable representation of Bengali regional parties but their successive failures to get negotiations going with the West Pakistani leadership, successive new Constitutions, the provisions for an Islamic State in 1956, and the imposition of martial law-the politics of separation between West and East Pakistan only grew deeper and gave increasingly sinister dimensions to the postcolonial state. With Mujibur Rahman (who had called for the liberation of East Pakistan as early as in 1956) assuming mainstream political power in the early 1960s, his just espousal of revamped economic policies to prevent the drain of resources from East Pakistan and arrest the increasingly glaring inequalities that rendered the province a virtual colony of its Western seat of power, and finally his six point political-economic programme announced in Lahore in 1966, the breach was nearly complete. In the first ever national elections in Pakistan (December 1970) where voters could finally elect their chosen members to the National Assembly directly, Rahman's Awami League received a thumping majority, but in an utter travesty of democracy, the government could never be formed. As the chief martial law administrator and President, General Yahya Khan took up a dual policy of mounting increasing number of troops 
upon East Pakistan on the one hand, and engaging in abortive talks with Rahman in Dhaka on the other.

It is in the light of these dismal developments that Rahman's (who by now had been christened 'Father of the Nation', and affectionately called 'Bangabandhu' meaning friend to every Bengali) historic 7 March 1971 address to the people of East Pakistan (henceforth known as Bangladesh) that has subsequently been included in UNESCO's heritage list, was delivered. His clarion call to every Bangladeshi citizen irrespective of gender, religion, caste, or creed to participate in armed resistance and an all-out struggle to liberate the motherland and achieve longdeferred independence has been looked upon as the greatest policy document (though delivered impromptu) that plunged a people into the final battle. Archived as a visionary document of visual culture, and against the backdrop of a 'civil war' (if seen from the West Pakistani point of view), this speech has connotative significance in the context of the present paper. In a situation where there were not much guns or armoury at the disposal of the East Pakistani civilian forces, Bangabandhu's call for armed resistance using whatever home-drawn objects that people could assemble, takes the signification of guns in this (broadly) subaltern uprising of the Bengali race to metaphoric dimensions. This could be seen as another dimension of the logistic constraints of unavailability of authentic weaponry for representation, and the roundabout ways of negotiating such absence mentioned by Mokammel as quoted in the interview earlier.

In his monograph Mujibnagar Sarkar o Bangladesher Muktijuddha (The Mujibnagar Government and the Liberation War of Bangladesh) Mohammad Fayekuzzaman (2017) rightly contrasts 15 August 1947 with 7 March 1971, the people's rejection of Pakistan being full and final on the latter date. Beginning on 25 March 1971 when the Pakistani army cracked down upon civilians and culminating on 16 December 1971 when the final surrender took place before the joint forces of India and the civilian army of Bangladesh, the civil war that raged over nine months has been one of the bloodiest epochs of the subcontinent, marked by brutal killings, rape and burning of human settlements, and civilian hit-back to it in all possible forms. With Rahman captured and interned in Pakistan, the world community came down heavily on his detention and warned of dire consequences, while a government in exile continued to direct the affairs of the state of Bangladesh at large and of the liberation war in particular. The reference to genocide in order to describe the incidents at Dhaka and elsewhere first came on 28 March 1971 from Archer K. Blood (2017), then US Consul General in Dhaka, who called it 'Selective Genocide' (Blood, p. 213), and that they were 'muted and horrified witnesses to a reign of terror by Pak military' (ibid., p. 213). Blood also informs that on 31 March 1971 , 'the Indian parliament passed a resolution in support of the 'people of Bengal' (302).

One of the earliest among the international community to voice pro-active concerns over the state of affairs in Pakistan, the Indian response was a complex assortment of state policies. First and foremost, the gross violation of human rights needed redressal and Prime Minister Mrs Indira Gandhi was quick to embark on a world tour as it were, to appeal to the international community. In the face of increasing brutalities by the Pakistani forces that followed a common pattern of burning houses and villages, indiscriminate killing that targeted Hindus and leaders of the Bengali community, people were left with no option but to begin a second wave of refugee influx to the relative safety of India. There were obviously limits to which the already stressed Indian economy could support these waves of battle-bruised teeming millions arriving incessantly. Blood writes that the flow of Hindu and Muslim refugees 'presented India with a huge and expensive problem, particularly in the Indian state of West Bengal' (303). Despite this India became a safe haven for the Bengalis as it was the seat of Bangladesh Government in exile. In fact, the government in exile, formed at Meherpur (renamed Mujibnagar) finally began to operate from Calcutta (now Kolkata). The Bangladesh Liberation War Archives clearly suggest that the youth of Bengal in large numbers were also crossing borders en masse to receive training in arms in Indian military establishments, to add systematic rigour to the Liberation War in Bangladesh. ${ }^{6}$ Besides India continued to provide constant and active strategic support to the Mukti Bahini, before she finally joined the armed conflict on 3 December 1971, after Pakistan had launched pre-emptive air-strikes on several air bases in North India. This Pakistani strategy of salvaging its eastern frontier by engaging India in the West proved futile, even as it further cemented Indo-Bangladesh ties in the long run.

\section{Films of the 1971 Bangladesh war of liberation}

In his interview with the authors, director Tanvir Mokammel, who has been an avid researcher on the Liberation War, said:

There were different kinds of freedom fighters in the more professional Bengal Regiment of the Pakistan Army, members of East Pakistan Rifles (EPR), police, Ansar, Mujahid and purely civilian freedom fighters, mostly students and young men from different walks of life. The freedom fighters from the armed forces had their professional guns and weapons, generally 303 rifles, some Chinese automatic rifles, light machine guns (LGM), even $2^{\prime \prime}$ or $3^{\prime \prime}$ mortars. But the ragtag civilian forces had all kinds of weapons, 303 rifles, mostly looted from the local police stations, $\cdot 22$ bore rifles, single- or double-barrel shotguns, pistols, even air-guns, used for shooting birds. You can see those weapons in their hands from the archival footages of that period. But after the guerillas got training in the Indian camps, the quality of their weapons supplied by the Indian Army improved which included stenguns (mostly made in Czechoslovakia) and hand grenades. (Huq, 2019).

In another interview on representations of this phase of the history of Bangladeshi life on celluloid, Mokammel accepts that there are issues like improper censor norms, the challenges to the availability of authentic weapons by film makers, as also the lack of adequate research coupled with waning audience interest. ${ }^{7} \mathrm{He}$ thus laments over the fact that in description of action-scenes, of which there was indeed a profusion in the real life of the nation during this period, films from Bangladesh still fall short in comparison with European cinema. All the same, he mentions that over the years of rule by the pro-Liberation government, there has been fair funding to such projects. The truth of all these facts are brought out by a number of films made in Bangladesh on the Liberation War, and over the years, one sees in them an evolutionary trend in the conception and presentation of guns, and even ways in which covert skirmishes are shown.

Amar Bandhu Rashed (My Friend Rashed, 2011) from Bangladesh. Directed by Morshedul Islam, Amar Bandhu Rashed, based on the eponymous novel by Muhammad Zafar Iqbal, as its title credit says, is produced under a grant from the Government of the People's Republic of Bangladesh. The film presents Rashed, an eighth grader who comes to live in a small town with his father at a time when the Liberation War has broken out. He and his school-friends get involved with the war and start helping freedom fighters in many ways. The film adopts a stream of consciousness technique using the narration of another boy (now a middle aged man with a son) named Rokibul Islam aka Ibu. He 
used to be Rashed's close friend, and when the film begins, Ibu is seen revisiting the town with his son and narrating the story of his brave friend Rashed, hence the naming of the film. In Ibu's recollection, while all other boys in the school were usually busy with adolescent activities, fun and games, Rashed used to remain aloof. $\mathrm{He}$ was strange but later his friends got to know that Rashed was actually deeply concerned about the political turmoil raging in the country. Not only was he well abreast of West Pakistan's designs, Rashed actually managed to have all updates of the ongoing war, and gradually started motivating his classmates to help the freedom fighters. They begin with supplying the muktijoddhas with information of the whereabouts of the Pakistani army. The film shows in detail this self-indoctrination by the youngsters, gives vivid pictures of civilian militia hideouts, and actually shows how young Rashed warms in and wins the confidence of the muktijoddhas. The time frame shown in the film is the early part of March 1971, when the West Pakistani suspension of the National Assembly where Sheikh Mujibur Rahman (also widely known now as Bangabandhu) was to assume power, had put the nation on fire. Dinajpur, which is the locale of the film, was rife with political activity and governmental repression against it, as in all parts of East Pakistan, and Rashed informs his friends of ongoing trainings for liberation army personnel followed by their being equipped with stenguns and hand grenades. Amar Bandhu Rashed shows this entire build up through the eyes of Rashed, now recollected by his friend Ibu.

In the face of stiff Pakistani surveillance, Rashed and his friends help hide ammunitions and later they carry those to the freedom fighters' camp at great risk. This scene where the boys are shown playfully trespassing the sentry barricades while fiddling with a football as they are strapped with bullet belts below their shirts is both exciting as also emblematic of the commitment of every ordinary citizen of Bangladesh to the cause of the Liberation War. Eventually, Rashed and his friend Ibu are also shown participating in direct combat, albeit surreptitiously, as the guerrillas execute their plan of attacking the local school where a military camp has been set-up. The visual impact of young Rashed taking over the Light Machine Gun (LMG) as the guerilla unit commander sustains injuries from enemy bullets is indeed Islam's courageous assertion of the truly pervasive nature of the Liberation War.

The use of guns by the Pakistan militia and rajakars who acted hand in glove with them, that Islam shows as Rashed is blindfolded and shot at the end of Amar Bandhu Rashed, brings home the grim reality of the situation. He is made to stand on swampy ground, is first fired on his legs by a local rajakar, and is asked to defect to the Pakistani side. Rashed refuses, defiantly stands his ground and pronounces 'Joy Bangla' (Victory for Bangladesh), whereupon he is fired a second time on his chest. As young Rashed falls to his death, and the muddy waters turn red with his blood, the film ends on a grim note of immediacy. The piquant use of guns in such a film registers an impact that is tentatively poised between the defiance of a people rising to claim their destiny, and the vested interests that drive some sections among the same people to heinous acts of sabotage and cruelty. In an interview with the authors, the director asserted that he saw much of himself in the protagonist of the film, and actually he knew of a real person of Rashed's likeness who was his elder brother's friend. Although he borrowed the script from Zafar Iqbal, Morshedul Islam actually found the story real (Interview taken on 16 November 2018 in Dhaka). He further added that the contribution of adolescents and young men in the war remains unsung and he wanted to highlight it. Jamil Mahmud's review (2011) of the film in The Daily Star is also insightful as far as the historical reality of adolescents wielding guns during the armed conflict, or falling victims to it are concerned:
We often hear teenagers these days show less interest in reading; rather, they are always busy with browsing the web, playing virtual games and watching films. Keeping that in mind, adaptation of Liberation War themed stories, novels and other fictional works into films is a way of encouraging the youngsters to get acquainted with the history of the nine month-long brutal war that freed the country. (3 April 2011).

It is a fact that in the new millennium films based on the theme of Liberation War are few in number. Amar Bandhu Rashed is certainly remarkable, and moreover, that it has been made particularly for adolescents is even more significant. Children and adolescents are supposed to know their history as they hold the keys to the future of the nation. According to Mahmud, the storytelling by a father to his son signifies the educative aspect of the film, as elders who had witnessed the war firsthand should share their experiences with post-war generations. In course of the narrative, the film also takes up related issues like the fears of the Hindu community and their migrations, the arming of local traitors by the Pakistani army, and even the visual delight that comes out of watching the diminutive Bengali in oversized fatigues carrying rifles that are too heavy for them. However, the overarching threat of brute state power that guns represent is strongly present in Amar Bandhu Rashed; while the counternarrative of hope that the film posits is still shaping as it were. The handling of firearms by adolescents might come for criticism in the sense of violation of child rights; but was indeed a war reality in 1971. The existence of numerous adolescent freedom fighters is evidenced during the war. The way Rashed and his friends are shown carrying bullet belts in the film is thus a representation of contemporary reality, wherein simulation and representation need to be demarcated. Jean Baudrillard comments, 'Whereas representation attempts to absorb simulation by interpreting it as a false representation, simulation envelops the whole edifice of representation itself as a simulacrum' (Baudrillard 1994, p. 6). An image, accordingly, is a reflection of profound ${ }^{9}$ reality that masks and denatures a profound reality and also its absence, and finally it has no relation to any reality and it becomes its own pure simulacrum (6). Baudrillard was much criticised for his book The Gulf War Did Not Take Place (1995), as he was assuming on reality, whereas the hyper-real was being vaunted in media representations of the Gulf War. In the initial essay 'The Gulf War will not take place' (published on 4 January 1991 in Libération) Baudrillard writes, 'War has entered into a definitive crisis. It is too late for the (hot) WW III: it has already taken place, distilled down the years into the cold war. There will be no other' (23). Indeed, Baudrillard was thinking in terms of power symmetry. The imbalance in military prowess of the US and Iraq was such that he could not believe when he saw television reports on the war. He had to write the second essay titled 'The Gulf War: is it really taking place?' (partially published in Libération on 6 February 1991). Paul Patton in his 'Introduction' to the English translation of the essays (compiled as the 1995 book) writes that perhaps Baudrillard considered the war to be 'an act of exercise in domination rather than an act of war' (19). Patton argues,

At the time, the TV Gulf War seemed to many viewers a perfect Baudrillardian simulacrum, a hyper-real scenario in which events lose their identity and signifiers fade into one another. Fascination and horror at the reality which seemed to unfold before our very eyes mingled with a pervasive sense of unreality as we recognised the elements of Hollywood script which had preceded the real [...] and as the signifiers of the past events faded into those of the present [...] Television news coverage appeared to have finally caught up with the logic of simulation. (2). 
Controlled and censored live television reports produced falsified images of a 'clean' war with a 'few images of human casualty and none from the allied forces' (3), it misguided Baudrillard as 'the virtual overtook the real' (8). However, Baudrillard's view on simulacrum finds currency in this discussion because later films like Commando and Bullet Babu analysed in this paper show the tendency of producing virtual violence that may not have connection with ground realities of every day Bengali life. Nonetheless, they prosper in the imaginary of the contemporary viewers because the simulated violence is experienced by them regularly on screen via Hollywood films and video games.

Juddhoshishu (dubbed in Bengali from the original Hindi Children of War, 2014) from India. While Morshedul Islam's Amar Bandhu Rashed subjectivises the adolescent taken into the vortex of the 'civil war', Mrityunjay Devrat's Juddhoshishu builds the narrative from the perspective of the survivors amongst children born out of the rape of uncountable Bangladeshi women by the Pakistan militia. There is rampant use of lethal weapons like revolvers, guns, and mortar shells, whereby the trigger-happy Pak troops are led by their sinister commanding officer Malik, or by the emergent forces of resistance that are regrouping in hideouts. Beyond the obvious display of such ammunitions, the film also uses the female body, both armed and unarmed, to critique an often veiled aspect of post-war state policy-the question of numerous forced pregnancies that left the surviving women destitute, and orphaned the children they gave birth to. While many such women and children did not survive the bestial cruelty, those that did were either physically maimed or unwelcome in their own families, and worst of all they never made a place in official narratives of independent Bangladesh as victims of the war. The paradox inherent in the rhetoric of calling them birangona $^{10}$ (war heroine) is severally exposed in Juddhoshishu as the raped women repeatedly insist that physical violation does not destroy their mental strength, or that they are not ashamed to script their stories in the new nation that will emerge from the cleansing fires of the Liberation War. This becomes an important statement urging the female subject's inclusivity in the bodypolitic of the emergent/cleansed nation, proclaiming a pyrrhic victory over the phallic brutality of guns and attendant ammunition. While the making of a film like this one that addresses such issues speaks of the inextricable ties that bind concerns of common people in both countries, one cannot lose sight of the fact that it did not get permission to shoot in authentic locales in Bangladesh.

Beginning with a suggestive evocation of Mrs. Indira Gandhi's spirited challenge to world leaders to rise against the perpetration of genocide, and followed by Bangabandhu's clarion call for independence through armed resistance, Juddhoshishu directly propels the viewer into the subversive use of guns. The story is set in Kushtia (East Pakistan) in 1971 and shows close parallels between the plight of Jews in Nazi Germany and the Bangladeshis in their own land. It opens to the unnecessary killing of a young Muslim boy who is dragged into the house of Aamir, who is a pro-liberation journalist; followed by physical violence on him for glorifying Bangladesh, and the rape of his wife Fida by Malik and his men who invade the privacy of their bedroom. From the outset therefore, the tone is set for the use of guns by the marauding enemy-perpetrate holocaust on the one hand, and serve as a phallic symbol of brute physical power that is devoid of moral strength on the other. The couple are obviously separated and while Fida lands up with many other women at a Pak detention camp where they are either subjected to multiple rape and impregnation or killed, Aamir joins an underground resistance group where he battles between his ideals and the ground reality till the fiery journalist finally learns to use the gun as a killer weapon. There is a parallel plot involving the teenage siblings Rafiq and Kausar, who are the only survivors in their village, and are on the run (despite acute starvation) to reach India, where they hope to survive. Rafiq graduates from wielding a stick for self-defence to taking up a gun that he acquires after overpowering a Pakistani soldier who is part of a contingent of killers that overpower a group of nomadic locals equally on the run for safety. The rite of Rafiq's initiation to ammunition and the utter hatred that leads the young boy to keep on firing upon the corpse of the dead soldier is a moving comment, no less impactful than the remorse writ large on Aamir's face as he makes his first kill with the gun. Young Rafiq however gets near redemption but fails to make it; he is shot from behind just as the siblings come to visualise the Indian border that they have so long been trying to reach. The sight of bereaved Kausar kneeling over the corpse of her brother, the only relationship she was left with in life, makes for one of the most haunting scenes of Juddhoshishu.

The most rib-chilling depiction of guns and ammunitions in this film is however found in the presentation of the character of Bhitika, who like Fida, is also apprehended by the Pak forces and detained at the camp for use as object of rape and torture at will. As a woman whose indomitable spirit and agency are extolled beyond words, she stealthily manages access to the armoury and sneaks out of the camp in exchange of sexual favours with the rajakar guard on the plea of having a fresh water bath. Strapped with bullet belts and armed with mortars, like Rashed and his friends in Amar Bandhu Rashed, Bhitika transports these to the guerrilla fighters of Aamir's group, acquires information and manages to blow out a military vehicle that kills Pakistani soldiers, and promises to come back with more supplies. In her next mission, she is however caught, and then follows the subhuman practice of her rape in full view of other detainees and at gunpoint, so as to exhibit exemplary punishment. The shooting of a badly bruised and battered Bhitika, and her death with eyes dilated, ends her story and leaves the viewer nauseated at the mindless motivation that alone can lead to such gross debasement of humanity. On the subject of the use of guns in Bangla cinema, Rashed in Amar Bandhu Rashed and Bhitika in Juddhoshishu mark an important point in cultural representation. Between them, there is much in common in the ways in which they become instrumental as 'soft' participants in the hard war by strapping bullets on their bodies and acting as carriers for their fighter brethren on the front. Their deaths too, have similar resemblance as gory spectres of the violation of the unarmed. Cumulatively, Rashed and Bhitika embody the sacrificial zeal of soft-targets (in stereotypes of gender attributes) to withstand physical pain of bayonets and psychological torment of oppressive and overpowering forces.

Juddhoshishu begins with a spirited declamation by a child of war that Fida has given birth (child of repeated rape) to, after being restored to her family; the film also ends with the child's repeated 'Joy Bangla' slogan, ultimately upholding the message that life is always greater than death, and firearms as the agencies of death are always defeated by the power of youth that represents moral and ideological strength. However, the establishment of the ideology has been executed through an imposed reality of the empowerment of the children of war, which in no way reflects the ground reality. In post war Bangladesh, these children were either aborted if there were possibilities, or were separated from their mothers and were given away from the rehabilitation camps setup for the raped women. ${ }^{11}$

\section{Contemporary reality and Bangla films}

Present day Bangladesh and West Bengal have multiple issues that might have been influencing the respective film industries. In 
Bangladesh, the assassination of Bangabandhu, the Father of the Nation and the amnesiac loss of ideological and emotional ties with the Liberation War caused by the reign of autocratic power for more than a decade, global economic transformation and rise of neo-liberal economies in its aftermath, a massive cultural flux - have all kept their marks on cultural identity and the resultant cultural products. After Bangabandhu's gruesome murder, Bangladesh witnessed the emergence of Bangladesh Nationalist Party in the hands of Ziaur Rahman, once the leader of the Z-force, one of the eleven sectors of the Liberation War, who became president of Bangladesh in 1977. His ascent to supreme power using military force is in many ways reminiscent of a similar decadence that Bangladesh despised about West Pakistan during the period of its persuasive-coercive occupation of East Pakistan. This was indeed a paradoxical turn of events whereby yesterday's freedom fighter became today's oppressor, the metaphoric turn of roles being activated at gunpoint as it were. During this time Bangladesh also witnessed the restoration of the anti-Liberation entity Jamaat-e-Islami, which has historically been one of the driving forces behind the Pakistani occupation of present day Bangladesh. In the 1990s Major General Hussain Muhammad Ershad established complete autocracy. Since the end of his regime Awami League and Bangladesh Nationalist Party have successively formed elected democratic governments by turns but both parties used student politics as a major weapon of their election victory. The use of illegal arms, crossfire and political killings have hence become a mark of contemporary political exercise.

A similar spate of changes in the socio-economic matrix has been witnessed in India since it opened its markets to the world in the neo-liberal era. Tension between linguistic and religious communities always existed since the Partition, but by days the tension between central government and insurgent peripheral communities has increased. West Bengal witnessed the Gorkhaland Agitation in 1986-1987. ${ }^{12}$ Additionally, religious fundamentalism and bigotry paved their ways into a new definition of 'Indian-ness' since the demolition of the Babri mosque in Ayodhya in $1992,{ }^{13}$ as these have been increasingly played upon as election tools.

Therefore, the general loss of control over violence and moral order in both Bangladesh and West Bengal kept its mark on their respective film industries. Several films in the new millennium hint at the fact. Perhaps there is also a marked influence of Hollywood action films on the locally produced ones. Since the last few years it has become a practice to release Hollywood big budget films simultaneously in all big cities of the world. Dhaka and Kolkata have been two major cities where at the big cineplexes (technologically advanced movie theatres) such films are screened. Rambo, Commando, James Bond, Indiana Jones, or even gun supermarket advertisements from the USA-such simulations were already known to Bengali public due to the films available on video cassettes or DVDs. These days a James Bond or Mission Impossible or Transformers sequel comes to the Bengali public instantly. Action and armed combats in films are, as an effort to keep Bangla film industries up-to-date, indispensable to many, though how much of it carries a meaningful social message remains to be interrogated. The reflections of such thoughts are visibly present in contemporary films. Video games too have added to this visual culture of simulated violence. The recent terror shooting at Christchurch mosque shooting has witnessed how a video game addict has satisfied his racist desires by killing 51 people in the mosques, after which the New Zealand Prime Minister has declared that there will be changes in the country's gun laws (New York Times, 17 March 2019). Simulated reality has been affecting human culture, and it is a cause for worry that Bangla films of the recent times, have also seized upon such populism in several ways. This is all the more worrisome because there are people of heterogeneous education and awareness levels flocking the theatres for such incredulous entertainment.

\section{Films of our time: simulated realities?}

Bullet Babu (2017) from Bangladesh. The third and last film from Bangladesh analysed in this paper is an extreme case of simulated reality. Directed by Mohammad Delwar Hossain Dilu, the story of Bullet Babu takes us to Chattogram (former Chittagong) and surroundings. The area is culturally enriched as many indigenous tribes live here in the hilly districts with the Bengalis from the plateau. However, there have been disputes over the hill tracts since the Bengal partition, as Chattogram was demarcated as an Indian territory in the first map of Cyril Radcliffe. Conflict over ethnicity and culture has been a recurrent pattern of life in this region, as continuous newspaper reports on land disputes between the indigenous people and the Bengali settlers will testify to. This area is geographically very important as it is a route for international trade via land, as well as seaways. Border tensions between Myanmar and Bangladesh have also been a fact since long that has culminated in the mass Rohingya genocide and exodus in 2017. The Bay of Bengal encircling the hilly districts has made it geographically priceless as a tourist spot, as also a vulnerable region politically. Illegal trafficking of weapons and drugs is a not only a possibility but an informed reality, as newspapers present the news of passage of trucks of illegal drugs and weapons through the region. None of these realities are however deemed necessary to be foregrounded in the film; rather it concerns only with highlighting the revenge motif through a highly fantastic and baseless story. It is the story of a son's revenge for the murder of his journalist father and his whole family by a mafia leader. All major and minor characters use different kinds of shotguns and rifles. The two gangsters, KD and Dunga, who are agents of a mafia leader called Badshah, frequently have shoot-out matches between them as it were. Babu, the protagonist, is an idealist without any apparent ideology except for a son's duty to avenge the murder of his parents and wife. This film is one of the many films that are made to entertain ordinary film spectators of Bangladesh. Firearms are used as toys in the film that may beguile a viewer into a hyper-real world that is created out of sheer arbitrariness by the director.

This film is an extreme example of hyper-reality as becomes visible from its scene by scene analysis. It is replete with the use of guns of all kinds-shotguns, pipe guns, rifles and pistols. At the outset two speedboats carrying a group of gangsters reach a remote island. The crew have shotguns and rifles. Their leaders, $\mathrm{KD}$ and Dunga, agents of a mafia leader called Badshah as mentioned earlier, shoot each other's gang on the island as they cannot agree on whether to betray the main mafia leader. A short scene from the film can be exemplary of how it has entered the simulated space crossing all limits of reality. During a meeting between Badshah's gangsters his faithful follower KD explains that he is called KD aka 'killer of the dark' because he cannot keep sanity without his daily course killing a few people every day. He comments, 'Khelche khela uparwala, ami saala pistolwala', which means 'God is playing His game, I am [with a slang] just a man with a pistol' (own translation). He seems to be deeply 'religious' insofar as his religion lies in blindly obeying his leader Badshah. Hence, the motives for killing and use of firearms are completely arbitrary. Baudrillard rationalises such arbitrariness thus:

It no longer needs to be rational, because it no longer measures itself against either an ideal or negative instance. It is no longer anything but operational. It is no longer really the real, because no imaginary envelops it anymore. It is a hyper-real, produced from a radiating synthesis of combinatory models in a hyperspace without atmosphere (2). 
In the context of Bullet Babu, guns seem to stand for manhood in the case of the mafia dons and also for the protagonist whose actions are represented in a rather cavalier manner all along the film. Such a use of guns to commodify violence, irrespective of the fair or foul potential of who is wielding it, is a remarkable contrast from the association of guns with characters in films of the Liberation War. In the context of the Liberation War as shown in the analysis of films above, there are clear dividing lines between the Pakistani army's use of it as visual symbols of phallic masculinity, while in the hands of muktijoddhas or even with the Indian army, guns are shown as being used in defence or in charging against the enemy. Even though the present film is located within the space of a national society, the use of guns as symbols of cowardice for the police, is paradoxical to say the least. Yet as the film stands, we see that with guns the police cannot establish their effectiveness as keepers of the law, and without them they are utterly nothing. On the contrary, guns are used to create an inevitable threat perception that mars the serenity of the beautiful mountainous settings, overshadow the vastness of the sea, and even fill urban spaces with terror. Therefore, the subversion of ecological perspectives in Bullet Babu is juxtaposed with a hyperspace in which the only objects that seem to matter are the guns.

Commando (2018) from West Bengal. Directed by Indra Prem and Barun Das, the Bangla film Commando (2018), a remake from Tamil, comes across in reception as an alarming expose of Baudrillardian hyper-reality, which by its very nature requires no original referent. This freedom, even from the demands of probability, is trickily exploited right from the title credits, where the directors mention that their work draws 'inspiration' from the most gruesome assassinations of the nineteenth and twentieth centuries across the world. The chronology begins from Abraham Lincoln (USA, 1865) and ends with Benazir Bhutto (Pakistan, 2007), including between them Mahatma Gandhi (India, 1948), John F. Kennedy (USA, 1963), Che Guevara (Bolivia, 1967), Bangabandhu Sheikh Mujibur Rahman (Bangladesh, 1975), and Indira Gandhi (India, 1984), a long line of national leaders who fell to assassin's bullets. That way, the sub-culture of guns as signifying disruptive/discursive ideologies is woven into the very conception the text. The killing of Rajiv Gandhi (India, 1991) by suicide bombers is the only different one, but broadly it conforms to this philosophy of violent internal strife. In a world order where global terror and Islamophobia go hand in hand, the title credits build the expectation of a film that will perhaps prioritise national integration as a cultural project, in the upkeep of which the commando force might play a vital role as part of an organised structure of national security.

There is, however, a deliberate ambivalence underlying the supposedly 'inspirational' statement that comes as a prelude to the film. Any hopes of a more just world are belied right from the protracted first scene (discussed in detail below), by the end of which one knows that Commando is the tale of a big bad world of terror, and of incredulous personal bravado trying to offset it. Apart from textual incredulity, there is something more that is contextually very disturbing about the film. One cannot debate on the unjust inhumanity that underlay the assassinations of all those leaders across the globe, or even take a position whatsoever in assigning reasons behind these killings. Irrespective of either, historical truth has it that their lives were lost because they fell foul of opposing ideologies, which their chosen assassins represented. The disruptive anti-state narrative of Commando however does not foreground any such ideological conflict; it is presented as the brainchild of a single individual (known only as
Huzoor) who is a Pakistani freak with the express motivation of destabilising the body-politic of the Indian nation.

In a distraught South Asian scenario marred by constant escalation of tensions between estranged neighbours India and Pakistan, a cavalier approach to internecine conflict as mooted in Commando can be a dangerous game that is deplorable as well. Here the sole motivation that drives the Huzoor is his disgruntlement at not being able to seize power the way he wanted to out of the spoils of the partitions of 1947 (IndiaPakistan) or 1971 (East and West Pakistan). He looks upon India as his personal enemy because of its pro-active role in the 1971 Liberation War of Bangladesh, and has since been playing kingmaker in Indian politics. His objective at present is to have the Prime Minister (referred all along as PM) exterminated, and to install in his place the Deputy PM, who is his lackey, so that he can become the de facto power centre and unleash anarchy while remaining behind the screen. The timing of the attempted killing, as he reveals in a conversation with his protégé, is prompted by the fact that the two nations are on the verge of signing a deal that might foster closer ties, and thereby make it for difficult for Huzoor to achieve his goals.

These deeper motives are however only gradually revealed in the film, which opens with a scene of a pitched battle between the Prime Minister's Special Protection Group (SPG) commandos and local police who are ambushed in an aviation oil-tanker in the middle of a runway of some Indian airport. Evidently, the SPG are escorting the premier in a convoy to his airplane, when they encounter this obstacle of an oil-tanker on the runway, and the skirmish soon begins. Immediately reminiscent of hard-core Hollywood action movies in being replete with the most modern kind of ammunitions like rifles, shotguns, and rocket launchers (with the police force) and pistols and Light Machine Guns (LMG) (with the SPG), the audience is taken for a toss. The SPG in India is an elite security force and it is obvious that when they are around, commanding authority over provincial police forces rests with them, and both work in tandem. It can, therefore, be intuited that an act of sabotage is afoot, but we have no clue and must perforce acquiesce with the mass addiction of watching violence bordering on limits of credibility albeit from a safe distance. It is all the more incredible because the setting is an airfield that is serving as departure area for the Prime Minister of a country whose civilians are always wary of restrictions that any kind of VIP movement clamps upon them. The ordeal of watching a shooting game sequence of brushfire, reload guns, and shoot again continues for the first twelve minutes of the film. In this span we witness indiscriminate firing that takes a toll of human lives on either side, destroys vehicles, and culminates in the shooting of the target (Prime Minister) by a cop who initially cringes and then fires two shots on the left of his chest that should have been fatal by average laws of physiognomy. Yet the Prime Minister survives (the treating doctor says he is a rare case of dextrocardia ${ }^{14}$ ), as does the SPG chief Ashok, the eponymous commando of the title. The Prime Minister of India being escorted in a non-bulletproof car whose window panes can be smashed to smithereens with fire from an LMG, being made to hold a bayonet to protect himself, and entreating with a police officer for his life-these are incidents one too many to believe by the farthest suspension of disbelief. However, more than that, the manner in which the opening scene trifles with established structures of national security, and accords a foolhardy treatment to all such paradigms for pandering to gullible audiences with fantasies of terror and violence is indeed worrisome.

With the Prime Minister hospitalised in a private facility where the SPG set-up their control room and turn the outfit into a veritable bastion, the key players behind the plot begin to emerge 
in subsequent scenes and the audience is treated to accompanying fodder. Most of the remaining part of the film involves a battle of wits and stunts between the SPG chief Ashok, and a professional killer named Saurav who is engaged by the Deputy Prime Minister to accomplish the once jinxed task of killing the Prime Minister. Ashok, reportedly the best in the trade internationally with his weird powers of dying and being resurrected, is another weird tossing of the limits of medical science. Along with a largely imbecile police force, SPG commandos willing to lay down their lives and yet remaining largely effete, and Ashok's girl friend Smita who is good at assuming disguises all on the sidelines, the two repeatedly engage in encounters both overt and covert that continues to wax eloquent on the use of pistols and other sophisticated ammunition. The film does conclude with the fairy tale ending of the wicked being wiped out and the rule of law being restored largely as a result of the SPG chief s alacrity and bravery, but it leaves questions one too many. In thus playing with the philosophy of 'Simulation', Commando dangerously hovers over and trivialises international concerns on the volatile terror situation of the Indian subcontinent. In devising the figure of the Huzoor, and his handmaiden the Deputy Prime Minister who is by birth a Muslim but has been smuggled into India disguised as a Hindu to make the most out of contemporary politics, there is much to be said. Not only do these turns of the plot brazenly reflect the current exclusivist principle of political Hindutwa ${ }^{15}$ that holds sway in India and threatens its culture of coexistence as a secular nation, the film also parochially exploits the post 9/11 global malaise of profiling Muslims as masterminds of terror. Abounding in the use of the most modern kinds of guns and rifles and given the incessant stream of bloodshed it unleashes, this too is another glaring instance of the generic use of guns with greater diversification and more lethal potential, as consumer items as in video and mobile games. There is no gainsaying what impact a film like Commando can have on a generation that is given to internalising worst forms of violence through such simulated means.

The authors perceive the implications of such films as have been taken in this third phase not just as ephemerally regaling audiences in theatres, but also its contextual significations vis-àvis the creed of violence and simulacra with regard to gaming cultures and the influence of Western films in countries of the global south. In countries like Bangladesh and India where strict censorship norms are prevalent to the extent that films on searing social issues interrogating the pitfalls of nation formation do not make it without cuts galore, it needs to be questioned how such representations like Bullet Babu or Commando get past censor boards. It is time we questioned the logic of allowing such mindless dynamites to be planted in the minds of our youth in a situation where our societies are still behind global standards of empowerment through education. The reverse possibility is that such a culture-scape is the inevitable result of the collective failure of ideology-fuelled protest over decades of neo-liberalisation of politics in a situation where the economy does not provide enough inclusivity for all. For it is then that the need for such vicarious means of fulfilment arises and finds its soft-targets in youth force that needs to be satiated anywhichways.

\section{Conclusion}

The films analysed in the paper map the transferal route of Bangla film culture from political and ideological realities to simulated hyper-reality. While the first wave of Bengali films doted on socio-cultural realities and existent moral combats in which the necessity of guns is minimal; the second wave manifested the need for national liberation in which use of guns became a political urgency. Finally the last set of films show that even though there are some cases of political unrest in a multifarious and segregated cultural combination within a single-nation state, the use of guns or the use of violence per se is many a times quite arbitrary and not justifiable enough. While the first generation of directors capitalised the middle class taste that looked for poetic justice in social life, the second or the post-war generation of directors were either driven by patriotic zeal or invested in national sentiments. However, the third largely relied on a retrogressive public psychology that internalised violence both in real life and on screen. Drawing upon mainstream Bangla cinema as a viable channel of film studies and cultural studies and locating therein the use of guns for over seven decades, this paper has tried to chart the course of the life and times of the Bengali community of South Asia. The authors hold that such a perspective has not been evidenced hitherto in any study of Bengali public life, the community as such never having been known much as a martial race. However, as the foregoing discussion on the use of guns has shown, it is simplistic to harbour any assumptions as such about the life of a community. There may be debates on the chosen texts, but given our logic of inclusion, we are of the opinion that the sociological concerns embedded in this study can be an emergent area of further study in interdisciplinary academic circles.

\section{Data availability}

All data generated or analysed during this study are included in this published article.

Received: 5 August 2019; Accepted: 3 December 2019; Published online: 21 January 2020

\section{Notes}

1 The term 'Bangla' is the endonym for Bengali. It has its origins in the Indo-Aryan family of languages, and is the most widely spoken tongue in Bangladesh. In India, it is the language of the people of West Bengal. With various dialectical variations, Bangla is one of the major spoken and written languages across the world. The present authors use the term to specifically imply the medium of language, while the speakers of the tongue are called Bengalis. Thus, language here becomes a medium that transcends boundaries and forms an integrated culture. This assumption forms the foundational core of this paper.

2 A look at the present political map of India will show that between 1947 and 1971, West and East Pakistan denoted the partitioned boundaries to the West and East of India respectively. During the Bangladesh Liberation of War in 1971 in which India played a pro-active role in support of (then) East) Pakistan, the West Pakistani strategy was to engage India on its Western frontier, in the expectation that such engagement would both weaken and dissipate India's involvement in the east. The terms Western and Eastern theatre therefore refer to the Indo-Pak war of 1971.

3 For instance, Urvashi Butalia in her seminal work The Other Side of Silence: Voices from the Partition of India tries to unearth the so far silenced history of the marginalised section of the Partition victims. According to her, 'There is little doubt that in the history of Partition, the stories of women, children, scheduled castes and many others, have been silenced both at the level of the State and at the level of history writing (351-352). However, Butalia's work also falls in the same paradigm, while Mukherjee's is a search for a paradigm shift.

4 A practice generally prevalent in the North-Western parts of India that involved an act of self-immolation by women in order to save their honour when defeat at the hands of an enemy seemed inevitable. Historians are divided whether such a practice came into effect only in case of inter-religious conflicts as between Hindus and Muslims.

5 Mukherjee remade Rajkahini in Hindi as Begum Jaan (2017) where he shifts identical action to its setting in Punjab, which was the western frontier of partition. The Radcliffe Line similarly arbitrarily drew out the boundaries of India and Pakistan, and the locale of the present film is a similar brothel between the towns of Shakargarh and Dorangla, that will be dissected as a result of partition. The use of guns in Begum Jaan, as all else in the story, resembles Rajkahini; and it becomes a commendable utterance of a different story of female resistance against the pervasive backdrop of partition violence in historical records and in cultural representation. 
6 One of the authors visited the Muktijuddo Archives in Dhaka on 18 November 2018.

7 Interview source: https://www.youtube.com/watch? $\mathrm{v}=\mathrm{IyY}$ j2xmkjY. Accessed on 26 July 2019.

8 Literally meaning 'Victory to Bengal' or 'Hail Bengal', 'Joy Bangla' was a slogan for both Bangladesh and West Bengal indicating nationalism. It became a strong political slogan for the Awami League in the 1970s, and in 1971 it was the battle-cry for one and all in the Liberation War of Bangladesh.

9 Sheila Glaser calls it profound while Mark Poster calls it basic reality. Cf. 'Simulacra and Simulation' by Jean Baudrillard, Selected Writings, ed. Mark Poster (Stanford; Stanford University Press, 1988), pp. 166-184. https://web.stanford.edu/class/ history34q/readings/Baudrillard/Baudrillard_Simulacra.html

10 The epithet Birangona was accorded to the raped women survivors of the Liberation war by the Bangladesh Government, especially in deference with the wishes of Sheikh Mujibur Rahman. While there is an embedded sense of valorising women who were violated through the employment of this term, the ambivalence of state policy on such women (which this film interrogates) has hence remained a sore in the collective unconscious of Bangladesh as a nation.

11 Nilima Ibrahim's book (1994) Ami Birangona Bolchi gives a clear view of the raped women and their unfortunate children. Nayanika Mookherjee's book (2015) The Spectral Wound: Sexual Violence, Public Memories and the Bangladesh War of 1971 also provides an insight into the inner lives of the rape victims.

12 The Gorkhaland Agitation was a ten months old agitation in the Darjeeling Hills of West Bengal since May 1986. It was led by Gorkha National Liberation Front (GNLF). A demand for Darjeeling as a separate state for Gorkhas existed since 1903, as the Gorkhas thought themselves as ethnically and culturally different from the Bengalis. The agitation took 1200 lives and culminated in the formation of Drjeeling Gorkha Hill Council (DGHC) in 1988. The demand for a separate hill state still persists, and successive governments in India, both state and central, have only selectively dealt with the issue within the expediencies of electoral politics.

13 Babri Masjid was a mosque supposed to have been built in $1528-1529$ by the Mughal Emperor Babur's commander Mir Baqi Tashqandi allegedly in the birthplace of the mythological figure of Rama whose story is narrated in the Ramayana, an ancient Indian epic. The site in question is in Ayodhya in Uttar Pradesh, India. There were several court disputes and public conflicts over the mosque, and following its demolition on 6 December 1992 by Hindu nationalist groups, India witnessed the largest communal riots since partition. There have been controversies galore surrounding the very fact of Lord Rama being a historical or a mythological figure. As recently as 9 November 2019, the Supreme Court of India, in deciding upon a title suit over possession of the disputed site, has ruled in favour of the Hindu majority, subscribing to the theory of Rama's birthplace being the specific site where the mosque stood before its demolition. Basing upon reports of the Archaeological Survey of India, it has been held that there was a non-Islamic structure upon which Babur might have had the mosque built. While the implications of this juridical decision are presently the subject of animated debated, it is an accepted fact that a radical political line of Hindutwa has in recent times threatened the erstwhile projection of India as a tolerant secular nation. The authors hold that the pitfalls of majoritarianism are bound to have deeper implications in the body-politic of India, with ramifications on a sub-culture of violence and religious profiling.

14 It is a rare cardiac condition where the heart points towards the right side of the chest than its normal leftward incline. It is a congenital condition and is accompanied by other organs too being located on the 'reverse' side of the body, than it is in case of average human beings. The authors hold that in Commando, such a rare physiognomical situation is also employed to test the limits of credibility.

15 As opposed to Hinduism as a faith with devotion in its wide mytho-religious pantheon, political Hindutwa is largely conceived as a nationalist project of extreme right wing politics that has been operational in India coterminous with the freedom movement. Broadly, it believes that Hindutwa is by itself a nationalist idea, and swears by a disputable concept of homogenised majoritarianism and its attendant cultural hegemony.

\section{References}

Baudrillard J (1983) Simulacra and simulations. Columbia UP, New York, NY (Translated by Paul Foss, Paul Patton and Philip Beitchman)
Baudrillard J (1994) Simulacra and simulations. Michigan UP, Ann Arbor, Translated by Sheila Faria Glaser

Baudrillard J (1995) The gulf war did not take place. Indiana UP, IN, Translated by Paul Patton

Blood AK (2017) The cruel birth of Bangladesh: memoirs of an American diplomat. University Press Limited, Dhaka

Fayekuzzaman M (2017) Mujibnagar sarkar o Bangladesher muktijuddho. Anarya, Dhaka

Huq S (2019) Nation, identity and alternative bangla cinema: conversing with tanvir mokammel (part II). In: The Daily Star (7 September). Available at http://103.16.74.140/literature/news/nation-identity-and-alternative-banglacinema-conversing-tanvir-mokammel-part-ii-1796581. Accessed 7 Sep 2019

Ibrahim N (1994) Ami birangona bolchi (the voices of war heroines). Jagrata Prakashani, Dhaka

Kaur R (2017) Skipping memories on partition and the intersensory field in subcontinental britain. Third text 31(2-3):387-418. Available from Sussex Research Online at http://sro.sussex.ac.uk/id/eprint/68459/. Accessed 1 Nov 2019

Mookherjee N (2015) The spectral wound: sexual violence, public memory, and the Bangladesh war of 1971. Duke University Press, Durham

Mahmud J (2011) Amar Bondhu Rashed: young courage under fire. In: The daily star (3 April). Available at https://www.thedailystar.net/news-detail-180203. Accessed 12 June 2019

Pandey G (2012) Voices from the edge: The struggle to write subaltern histories. In: Vinayak C (ed.). Mapping subaltern studies and the postcolonial. Verso, London and NY, pp. 281-299

The New York Times (2019) 'There will be changes' to gun laws, new zealand prime minister says. In: The New York Times (17 March). Available at https:/www.nytimes.com/2019/03/17/world/asia/new-zealand-shooting. html. Accessed 16 Nov 2019

\section{Acknowledgements}

Editorial team of Palgrave Communications and the editor of the special issue are duly acknowledged. The film directors interviewed and quoted in the article are also acknowledged accordingly.

\section{Competing interests}

The authors declare no competing interests.

\section{Additional information}

Correspondence and requests for materials should be addressed to S.H.

Reprints and permission information is available at http://www.nature.com/reprints

Publisher's note Springer Nature remains neutral with regard to jurisdictional claims in published maps and institutional affiliations.

\section{@ 0}

Open Access This article is licensed under a Creative Commons Attribution 4.0 International License, which permits use, sharing, adaptation, distribution and reproduction in any medium or format, as long as you give appropriate credit to the original author(s) and the source, provide a link to the Creative Commons license, and indicate if changes were made. The images or other third party material in this article are included in the article's Creative Commons license, unless indicated otherwise in a credit line to the material. If material is not included in the article's Creative Commons license and your intended use is not permitted by statutory regulation or exceeds the permitted use, you will need to obtain permission directly from the copyright holder. To view a copy of this license, visit http://creativecommons.org/ licenses/by/4.0/.

(C) The Author(s) 2020 